\title{
Menopausal Symptoms and Health-Promoting Lifestyle Behaviors among Women in Tanta, Egypt: An Analytic Cross-sectional Study
}

Ehab A. Abo-Ali ${ }^{*}$, Ayat A. Oka ${ }^{2}$

${ }^{1}$ Public Health and Community Medicine Dept., Faculty of Medicine, Tanta University

${ }^{2}$ Psychiatric and Mental Health Nursing Dept., Faculty of Nursing, Tanta University

\begin{abstract}
:
Background: Although menopause is a normal physiologic stage of women's life, a considerable proportion of them are likely to experience various symptoms during this period. Menopausal symptoms could adversely affect the physical, mental, and social well-being of menopausal women. Objectives: To study the relationship between health promoting lifestyle behaviors and menopausal symptoms among Egyptian women. Methods: Two hundred menopausal women were recruited randomly from all attendees presented to outpatients' clinics of Tanta University Hospital. For all participants, sociodemographic, medical profile, Health Promotion Lifestyle Profile-II (HPLP-II) and Menopause Rating Scale (MRS), were assessed through self-administered questionnaire or personal interview. Results: The average of total Health-Promoting Lifestyle Profile-II score was moderate among the studied menopausal women (120.38 \pm 16.63$)$, with the highest scores of its subscales were for "Spiritual" domain followed by "Interpersonal Relations" and the lowest scores were for "Physical Activity" and "Healthresponsibility" subscales. A significant negative statistical correlation was found between healthpromoting lifestyle behaviors scores (total and subscales), and menopausal symptoms. critical Factors (age, educational level, income, marital status, and occupation) had significant statistical association with health-promoting behaviors. Conclusion: Health promoting behavior correlated negatively with menopausal symptoms in the participating women. Health education programs about health-promoting lifestyle behaviors could reduce women's menopausal symptoms and improving their quality of life.
\end{abstract}

Keywords: Menopause, Well-being Practices, Women

\section{Introduction:}

Recently, many health systems developed their programs based on family health. In this regard, women are at the core of family health as they not only manage other family members' health condition, but also represent the main guide of education and promotion of a healthy lifestyle to the next generations. Moreover, women constitute the bigger part of population in most age groups.

Furthermore, their average life expectancy is longer than men even though they have a higher disease burden. Women must face specific problems arising from their natural physiological conditions, such as menopause. ${ }^{(1)}$ Overall, by increasing life expectancy, more than one third of a woman's life is spent in menopause, which cause many of physical and psychological changes in women. ${ }^{(2)}$

Although menopause is a normal physiological stage of women's life, a significant proportion of women are likely to have various problems during this period. Moreover, epidemiological studies have shown that approximately $65-85 \%$ of the women go through menopause symptoms, including hot flashes, sweating, palpitation, sleep disorder, irritability, lethargy, depressed mood, insomnia, aching in muscles and joints, short breath, weight gain, increased facial hair, anxiety, sexual problems, and urinary tract problems.

These symptoms decrease women's health and affect their biological, psychological, and social health. ${ }^{(3,4)}$ Health promotion and lifestyle 
improving are basic requirements in human societies. Health promotion is defined as the science and art of lifestyle change for achieving health perfection. The main aim of health promotion is to achieve healthy lifestyle behaviors. Healthy lifestyle behaviors include self-actualization, health responsibility, exercise, nutrition, interpersonal relations, and stress management. ${ }^{(5.6)}$

Health-promoting behaviors are one of the main effective components of health as a known underlying factor in the prevention of many diseases. Health promotion and prevention of diseases are associated with these behaviors, so following these health-promoting behaviors is one of the best ways by which people can protect and control their health. ${ }^{(7)}$ Health promotion includes behaviors in which the individual selects proper nutrition, regular exercise, avoid destructive behaviors and drugs, protection against accidents, early diagnosis of symptoms physical and emotional-related diseases, control of feelings, away from stress and fatigue, and sleep for 7 to 8 hours. ${ }^{(8)}$ Walker et al. have categorized health-promotion behaviors based on the health promotion model into six subscales: health responsibility, physical activity, nutrition, spiritual growth, stress management, and interpersonal relations. ${ }^{(9)}$

Women in menopause should be familiar and aware with dimensions of healthy lifestyle and should be encouraged to apply health-promoting behaviors for controlling signs and side-effects of menopause. The present study was conducted behaviors and menopausal symptoms among women in Tanta, Egypt.

\section{Methods:}

Study Design: The present study followed a cross-sectional analytic study design.

Study Setting: The study was carried out at the outpatient clinics of Tanta University Hospital, Egypt; over a period of three months from May to July 2019. This clinic serves a large geographic area in the Delta region in Egypt, with a wide spectrum of sociodemographic characteristics of the population.

Participants: All female attendees aged 45 years and more, presented to the general reception department of the outpatient clinics (patients and their companions), were interviewed by the researchers to ensure that they are have been in menopause for at least one year, having menopausal symptoms, didn't use hormonal replacement therapy and their menopause was not as result of surgical intervention or radiation therapy. All females fulfilling the previous characteristics were eligible to be included in the study. Study subjects were recruited by systematic random technique. The time needed for filling the questionnaire for individual case was between 15-20 minutes in average. The target sample size of 200 participants was achieved through a period of three months, from May to July 2019. Tool: The data of this study was collected using a questionnaire sheet which was selfadministered for educated participants, or by interviewing the illiterates and lower educated to assess the health-promoting lifestyle 
ones. From every participant the following data were collected:

i) Sociodemographic and health profile; age, residence, marital status, number of offspring, family income, educational level, employment, family accommodation, smoking, body weight status and chronic disease history.

ii) Menopause Rating Scale (MRS); MRS was developed by Heinmann et al. in $2003^{(10)}$. It consists of 11 items (symptoms or complaints) categorized into three subscales, namely, somato-vegetative, psychological and urogenital symptoms. The somato-vegetative subscale includes "sweating/hot flushes, heart discomfort, sleep problems, and joint and muscle problems". The psychological subscale includes "depressive mood, irritability, anxiety, and physical/mental exhaustion". Lastly, the urogenital subscale includes "bladder problems, sexual problems, and vaginal dryness". The items are scored on a 5-point Likert scale ranging from 0 (no symptom) to $4,(1=$ mild, $2=$ moderate, $3=$ severe, $4=$ very severe) depending on the severity of the complaints perceived by women. The total score of MRS is computed by summing up the points of each item and ranges between 0 (asymptomatic) and 44 (highest degree of complaints). The total score is determined by summing up the scores for each item. Higher MRS scores denote more severe symptoms. A total MRS score of 17 or greater was defined as severe degree of symptoms. Heinemann et al. in 2004 have used cutoff values to define severe symptoms according to each subscale; somatic (>8), psychological (>6), and urogenital (>3)..$^{(1)}$

iii) Health Promotion Lifestyle Profile-II (HPLP-II); this instrument was designed by Walker, Sechrist and Pender in 1987 to measure health promoting behaviors. ${ }^{(9)}$ Fifty two health promoting lifestyle behaviors are measured in a four point Likert scale for each item ranging from 1 (never) to 4 (routinely). The HPLP-II includes six subscales: health responsibility (9 items), physical activity (8 items), nutrition (9 items), spiritual growth (9 items), interpersonal relationships (9 items), and stress management (8 items). The overall score of the instrument ranges from 52 to 208, where each domain has its own separate score and higher scores indicate a better adherence to health promoting behavior. In this way, scores 52-103 means a low level of adherence to these behaviors and scores 104155 and score above 156 imply a moderate and high level, respectively. Additionally, the total score of each subscale is calculated by computing the mean of responses to that subscale's items. The total score is obtained by calculating the mean of responses of all the 52 items.

Ethical Considerations: Approvals of the Institution Review Board and the administration of the outpatient clinic were obtained prior conduction of the study. Informed consent was obtained from each study participant. Explanation the purpose of the study with emphasis on their right to withdraw from the study at any point was assured. Privacy of the 
participants and confidentiality of the collected data were guaranteed.

Data management: The collected data were organized, coded, tabulated and statistically analyzed using SPSS software (Statistical Package for the Social Sciences, version 19, SPSS Inc. Chicago, IL, USA). For quantitative data, range, mean and standard deviation were calculated. For qualitative data, frequency and percentage was used. For comparing means of two groups of parametric data of independent samples, student t-test was used. For comparing more than two means of parametric data, $\mathrm{F}$ value of ANOVA test was calculated. Statistical significance level was adopted at $\mathrm{p}<0.05$.

\section{Results:}

Table (1) shows basic characteristics of the studied menopausal women from outpatient clinic in Tanta University Hospital. It was observed that the highest frequency of them were $(83.0 \%)$ aged more than 55 years and $76 \%$ of them were unemployed. More than half $(52.0 \%)$ of them were illiterate. Three quarters of study participants (75\%) were rural residents. Most study participants were married (66\%) and the great majority of them declared to have enough income (82\%). Also, it was observed that nearly all the studied menopausal women (96\%) were living in cohesive families and most of them had chronic diseases and overweight/obese (73\% and $77 \%)$, respectively.

Table (2) shows scores and ranks of HealthPromoting Lifestyle Profile-II (HPLP-II) domains among the studied menopausal women from outpatient clinic in Tanta university hospital. Regarding the total Health-Promoting Lifestyle Profile-II, it was found the studied menopausal women had moderate health promoting behavior total score $(120.38 \pm 16.63)$. Regarding health promoting behavior subscales, it was observed that the highest scores were spiritual domain followed by Interpersonal Relations and the lowest scores were for physical activity and Health-responsibility.

Table (3) shows scores and ranks of severity of Menopause Rating Scale (MRS) subscales among the studied menopausal women from outpatient clinic in Tanta University Hospital. Regarding the total Menopause Rating Scale (MRS) Score, it was found the studied menopausal women reported severity of symptoms of Menopause Rating Scale (MRS) Score of (17.94 \pm 3.90$)$. In relation to Menopause Rating Scale (MRS) subscales ranking, it was observed that the first rank was for Somatovegetative symptoms $(1.96 \pm 0.55)$ followed by Psychological symptoms $(1.45 \pm 0.63)$, and Urogenital symptoms (1.44 \pm 0.70$)$, respectively.

Table (4) shows correlation between of Menopause Rating Scale (MRS) (subscales and total scores) and Health-Promoting Lifestyle Profile-II (domains and total scores) among the studied menopausal women from outpatient clinic in Tanta university hospital. There was negative significant correlation between health promoting behavior total score and menopausal symptoms total scores $(\mathrm{r}=-0.865, \mathrm{p}=0.0001)$. Regarding correlation between health promoting behavior total scores and menopausal symptoms subscales scores; a significant Egyptian Family Medicine Journal (EFMJ) Vol .5(1), May $2021 \quad$ http://efmj.journals.ekb.eg/ (c) (1) This article is an open access article distributed under the terms and conditions of the Creative Commons Attribution (CC BY) license (http://creativecommons.org/licenses/by/4.0/ 
negative correlation between HPLP-II total scores and menopausal symptoms subscales scores namely Psychological symptoms and Urogenital symptoms ( $\mathrm{r}=-0.543$ and -0.915 , respectively) and $\mathrm{p}=0.0001$. On the other hand, no correlation between total HPLP-II scores and Somato-vegetative symptoms subscale of Menopause Rating Scale (MRS) $(r=0.086, p=$ 0.393).

Table (5) highlights the relation between total Menopause Rating Scale (MRS)score and sociodemographic and health characters of study group; it was found that there is a significant relation between severity of menopausal symptoms and rural residence, married/widowed, lower educational level, more offspring, living in a cohesive family and smokers $(p<0.05)$. On the other hand, the relation between total HPLP-II scores and the same variables of study group, it was found that there is a significant relation between better health promoting profile and being married, with lower number of offspring, higher educational levels, employed and living in a cohesive family $(\mathrm{p}<0.05)$.

\section{Discussion:}

Physiological changes of menopausal period are very important as they influence psychological, social, and emotional aspects of women life. The improvement of healthpromoting lifestyle behaviors is one of the effective measures to moderate these symptoms by facilitating the women to enhance their lifestyle behaviors through making proper choices. ${ }^{(12)}$ The current study revealed that the

studied menopausal women had moderate health promoting behavior total score. This in line with a study was done by Bakouei et al 2017 in Iran. ${ }^{(13)}$ These results are also like another study conducted by Park S among Korean perimenopausal middle-aged women. ${ }^{(14)}$ In a study among Taiwanese women; the overall score for health promoting lifestyle behaviors was within the low range, a considerable predictor was attributed to the inability to read in Chinese. This indicates cultural differences between different countries. ${ }^{(15)}$

Regarding health promoting behavior subscales, it was observed that the highest scores were in the spiritual domain followed by interpersonal relations and the lowest scores were for physical activity and healthresponsibility. This in concordance with another study found a high mean score of spiritual domain which is similar to the menopausal Iranian women of a fore mentioned study. ${ }^{(13)}$ This can be attributed to the Islamic rules in spiritual enhancement. Spirituality gives people meaning and direction in life and provides a harmonious and integrated relationship between the internal forces. Moreover, our study participants' health responsibility scores were low, and these results were in concordance with other studies ${ }^{(16.17)}$. It could be explained as individuals did not consider their health control as a necessity. Mostly, subjects will not do anything to promote his/her health unless he/ she has problems with it.

Similarly, the high score in the HPLP-II subscales of women was found for interpersonal 
relations and spiritual growth and the lowest for the physical activity subscale have been reported in another study similar with our findings. ${ }^{(18)}$ The women who scored highest in interpersonal relations might have been influenced by the local cultures that have a cordial relationship in their families as well as the society.

In this study female have the lowest score in physical activity; this is similar to a study in 2012 that was conducted on middle-aged Iranian women. ${ }^{(16)}$ In another study that was conducted among nurses working in Ankara University Medical Faculty Hospital in Turkey, it was found that $77.0 \%$ of them were overweight which was attributed to the lack of physical activity. ${ }^{(19)}$ Women in general, especially in traditional communities, do not perceive physical activity as part of a healthy lifestyle because of cultural or personal reasons. In general, women are distinctive in mental health dimensions of HPBs such as stress management, interpersonal relations, and spiritual growth. However, their behaviors in the physical health dimension (physical activity, health responsibility and nutrition) that may negatively impact their physical health later in life.

On the other hand, the relation between total HPLP-II scores and the same variables of study group, it was found that there is a significant positive relation between better health promoting profile and being married, with lower number of offspring, higher educational levels, employed and living in a cohesive family. This study also shows a significant correlation for total health behaviors and weight. A similar study on postmenopausal women also showed a significant relationship between the whole score of health promoting behavior and lower body mass index of women and their level of education. ${ }^{(20)}$

Educational level was one of the effective factors in health promoting behaviors; women with higher educational level had better status which is in concordance with another study. ${ }^{(21)}$ In the current study, it was found that with increase in the number of children, health promoting life style status got poor, which was in concordance with the study by Enjezab et al. ${ }^{(16)}$ but Wang $\mathbf{J}$ and Geng $\mathrm{L}^{(22)}$ did not report significant statistical relationship in their study. Women with more children have less time to take care of themselves in comparison with those with fewer children. Opposite to expected, lack of statistical difference in the HPLP-II subscales between the employed women and housewives was found, this could be explained by the opposing effects of negative factors as increased stress and positive factors such and self-confidence. ${ }^{(23)}$ As predicted, the current study showed a positive significant relationship between the economic status and the whole score of lifestyle. This finding was in concordance with the studies conducted by Wang J and Geng L in 2019. (22) Adequate income is an important factor in individual's effective use of health care services. Additionally, financial stability has a positive effect on health promoting behaviors such as 
using appropriate sport facilities and having healthy nutrition.

Regarding the total Menopause Rating Scale (MRS) score, it was found the studied menopausal women reported a high severity of symptoms of Menopause Rating Scale (MRS) score. Regarding the subscales of Menopause Rating Scale (MRS ranking, it was observed that the first rank was for Somato-vegetative symptoms followed by Psychological symptoms and the last was the Urogenital symptoms. This in line with a study assessing the severity of the menopausal symptoms and showed that nearly half of the participants had severe total menopausal symptoms. More than two-thirds had mild to moderate somatic symptoms, whereas more than half of them had psychological symptoms and severe urogenital symptoms. This was explained by that majority of menopausal women were not aware about hormone replacement therapy that can alleviate the severity of menopausal symptoms. ${ }^{(23)}$ On the other side, Farahat et al. ${ }^{(24)}$ stated that more than one-third of women had urinary bladder problems in their study among women in an Egyptian village. The reason behind severity of symptoms is poor knowledge that may be due to inappropriate sources of information. Knowledge of menopause was found to be crucial in improving ability to manage menopause.

Regarding correlation between Menopause Rating Scale (MRS) (subscales and total scores) and Health-Promoting Lifestyle Profile-II menopausal women, there was negative significant correlation between health promoting behavior total score and menopausal symptoms total scores. Regarding correlation between health promoting behavior total scores and menopausal symptoms subscales scores; a significant negative correlation between HPLPII total scores and menopausal symptoms subscales scores namely, Psychological symptoms and Urogenital symptoms. On the other hand, no correlation between total HPLPII scores and Somato-vegetative symptoms subscale of Menopause Rating Scale (MRS). This is in agreement with findings of the study conducted by J. Moilanen et al. ${ }^{(25)}$ on Finnish post-menopausal women that proved a relationship between menopause symptoms and lifestyle. Based on these results, unhealthy lifestyle could increase the occurrence and severity of menopausal symptoms. Therefore, the unhealthy lifestyle positively correlates with the severity of menopause symptoms. Unhealthy lifestyle is one of the risk factors for cardiovascular disease and osteoporosis in menopausal women, which can increase the incidence and severity of menopausal symptoms. ${ }^{(26)}$ Debra Anderson carried out a study on Australian postmenopausal women and proved that a multidimensional intervention through implementation of a twelve-week educational program on healthy lifestyle was effective in boosting health-promoting behaviors and alleviating menopausal symptoms. 
The results of post-test of that study showed a significant reduction in psychological manifestations, hot flushes, night sweats, and physical conditions in the group that had received face-to-face education and counseling. ${ }^{(27)}$ Regarding the relation between total Menopause Rating Scale (MRS) score and socio-demographic and health characters of study group, it was found that there is a significant relation between severity of menopausal symptoms and rural residence, married, lower educational level, more offspring, living in a cohesive family and smokers. These results were supported by Bener et al. (2016) who studied psychological symptoms in menopausal Arab women, and reported that there were statistically significant differences between menopausal symptoms regarding age, educational levels, occupation status, and place of living. ${ }^{(28)}$

Limitations: The study was conducted in a governmental hospital, so presentation of females with high economic levels was not guaranteed.

Conclusions: The results of the study showed that menopausal women's health promoting lifestyle status was average. Women's highest mean scores were in "spiritual growth" and lowest mean scores were in "physical activity". Sedentary lifestyle is an important threat to postmenopausal women. The study also concluded that menopausal women reported a high severity of symptoms of Menopause Rating Scale (MRS). The first rank was for Somatovegetative symptoms followed by
Psychological symptoms, and Urogenital symptoms, respectively. There was negative significant correlation between health promoting behavior total score and menopausal symptoms total scores. Moreover, a significant negative correlation between HPLP-II total scores and menopausal symptoms subscales scores namely, psychological, and urogenital symptoms. On the other hand, no correlation between total HPLP-II scores and Somatovegetative symptoms subscale of Menopause Rating Scale (MRS). Regular training programs in the field of menopause and healthy lifestyle are very necessary to empower postmenopausal women to control and reduce the menopausal symptoms. One of the most important duties of health settings is taking care of postmenopausal women and to explain health promoting behaviors, in addition to designing and performing educational and interventional plans to create motivation towards a healthy lifestyle.

Acknowledgment: Our gratitude goes to the study participants who took part in this work.

Fund: The research was conducted with no fund.

Conflict of Interest: There was no conflict of interest as well.

\section{References:}

1. Santoro N, Epperson CN, Mathews SB. Menopausal Symptoms and Their Management. Endocrinol Metab Clin North Am. 2015;44(3):497-515. doi:10.1016/j.ecl.2015.05.001

2. Ibrahim ZM, Sayed Ahmed WA, El-Hamid SA. Prevalence of menopausal related 
symptoms and their impact on quality of life among Egyptian women. Clin Exp Obstet Gynecol. 2015;42(2):161-167.

3. Sánchez-Rodríguez MA, Castrejón-Delgado L, Zacarías-Flores M, Arronte-Rosales A, Mendoza-Núñez VM. Quality of life among post-menopausal women due to oxidative stress boosted by dysthymia and anxiety. BMC Womens Health. 2017;17(1):1. Published 2017 Jan 3. doi:10.1186/s12905-016-0358-7

4. Bansal R, Aggarwal N. Menopausal Hot Flashes: A Concise Review. J Midlife Health. 2019;10(1):6-13. doi:10.4103/jmh.JMH_7_19

5. Golden SD, McLeroy KR, Green LW, Earp JA, Lieberman LD. Upending the social ecological model to guide health promotion efforts toward policy and environmental change. Health Educ Behav. 2015;42(1 Suppl):8S-14S.

doi:10.1177/1090198115575098

6. Ford ES, Bergmann MM, Boeing H, Li C, Capewell S. Healthy lifestyle behaviors and all-cause mortality among adults in the United States. Prev Med. 2012;55(1):23-27. doi:10.1016/j.ypmed.2012.04.016

7. Mirghafourvand M, Baheiraei A, Nedjat S, Mohammadi E, Charandabi SM, Majdzadeh R. A population-based study of healthpromoting behaviors and their predictors in Iranian women of reproductive age. Health Promot Int. 2015;30(3):586-594. doi:10.1093/heapro/dat086
8. Sonmezer H, Cetinkaya F, Nacar M. Healthy life-style promoting behaviour in Turkish women aged 18-64. Asian Pac J Cancer Prev. 2012;13(4):1241-1245. doi:10.7314/apjcp.2012.13.4.1241

9. Walker SN, Sechrist KR, Pender NJ. The Health-Promoting Lifestyle Profile: development and psychometric characteristics. Nurs Res. 1987;36(2):76-81. 10. Heinemann LA, Potthoff P, Schneider HP. International versions of the Menopause Rating Scale (MRS). Health Qual Life Outcomes. 2003;1:28. Published 2003 Jul 30. doi:10.1186/1477-7525-1-28

11. Heinemann LA, DoMinh T, Strelow F, Gerbsch S, Schnitker J, Schneider HP. The Menopause Rating Scale (MRS) as outcome measure for hormone treatment? A validation study. Health Qual Life Outcomes. 2004;2:67. Published 2004 Nov 22. doi:10.1186/1477-7525-2-67

12. Núñez-Pizarro JL, González-Luna A, Mezones-Holguín E, et al. Association between anxiety and severe quality-of-life impairment in postmenopausal women: analysis of a multicenter Latin American cross-sectional study. Menopause. 2017;24(6):645-652. doi:10.1097/GME.0000000000000813

13. Bakouei S, Bakouei F, Omidvar S, Bakhtiari A. Health-Promoting Behaviors and Their Predictors in Iranian Women of Reproductive Age: A Cross-Sectional Study. Int $Q$ Community Health Educ. 
2017;38(1):3-8.

doi:10.1177/0272684X17747053

14. Park S. Mediating effect of a healthpromoting lifestyle in the relationship between menopausal symptoms, resilience, and depression in middle-aged women [published online ahead of print, 2019 Dec 6]. Health Care Women Int. 2019;1-17. doi:10.1080/07399332.2019.1685524

15. Lee FH, Wang HH. A prelimary study of a health-promoting lifestyle among South Asian women in Taiwan. Kaohsiung J Med Sci. 2005;21(3):114-120. doi:10.1016/s1607-551x(09)70287-6

16. Enjezab B, Farajzadegan Z, Taleghani F, Aflatoonian A, Morowatisharifabad MA. Health Promoting Behaviors in a Population-based Sample of Middle-aged Women and its Relevant Factors in Yazd, Iran. Int J Prev Med. 2012;3(Suppl 1):S191S198.

17. Li J, Yu J, Chen X, Quan X, Zhou L. Correlations between health-promoting lifestyle and health-related quality of life among elderly people with hypertension in Hengyang, Hunan, China. Medicine (Baltimore). 2018;97(25):e10937. doi:10.1097/MD.0000000000010937

18. Kutob RM, Yuan NP, Wertheim BC, et al. Relationship Between Marital Transitions, Health Behaviors, and Health Indicators of Postmenopausal Women: Results from the Women's Health Initiative. $J$ Womens Health (Larchmt). 2017;26(4):313-320. doi:10.1089/jwh.2016.5925 19. Kirag N,
Ocaktan EM. Analysis of health promoting lifestyle behaviors and associated factors among nurses at a university hospital in Turkey. Saudi Med J. 2013;34(10):10621067.

19. Asrami FS, Hamzehgardeshi Z, Shahhosseini Z. Health Promoting Lifestyle Behaviors in Menopausal Women: A CrossSectional Study. Glob $J$ Health Sci. 2016;8(8):53486. Published 2016 Aug 1. doi:10.5539/gjhs.v8n8p128

20. Harooni J, Hassanzadeh A, Mostafavi F. Influencing factors on health promoting behavior among the elderly living in the community. $J$ Educ Health Promot. 2014;3:40. Published 2014 May 5. doi:10.4103/2277-9531.131921

21. Wang J, Geng L. Effects of Socioeconomic Status on Physical and Psychological Health: Lifestyle as a Mediator. Int $J$ Environ Res Public Health. 2019;16(2):281. Published 2019 Jan 20. doi:10.3390/ijerph16020281

22. Shafaie, FS, Mirghafourvand M \& Momeni K. Health promoting behaviors and their relationship with general health in menopausal women of Langroud city. Int $j$ women's health and reprod sci. 2017;5(4):301-305.

23. Farahat TM, El Esergy FA, El Shopaky SA. Risk factors for overactive bladder in postmenopausal women attending Kafr ElBaramoon Family Health Unit, Egypt. Menoufia Med J [serial online] 2019 [cited 2020 Jul 5];32:139-44. Available $\begin{array}{lcc}\text { Egyptian Family Medicine Journal (EFMJ) } & \text { Vol .5(1), May } 2021 & \text { http://efmj.journals.ekb.eg/ } \\ \text { @ (- This article is an open access article distributed under the terms and conditions of the Creative Commons Attribution (CC BY) }\end{array}$ license (http://creativecommons.org/licenses/by/4.0/ 
from: http://www.mmj.eg.net/text.asp?2019 /32/1/139/256105

24. Moilanen J, Aalto AM, Hemminki E, Aro AR, Raitanen J, Luoto R. Prevalence of menopause symptoms and their association with lifestyle among Finnish middle-aged women. Maturitas. 2010;67(4):368-374. doi:10.1016/j.maturitas.2010.08.007

25. Pérez JA, Garcia FC, Palacios S, Pérez M. Epidemiology of risk factors and symptoms associated with menopause in Spanish women. Maturitas.2009;62(1):30-36.

doi:10.1016/j.maturitas.2008.10.003

26. Anderson D, Seib C, McGuire A, PorterSteele J. Decreasing menopausal symptoms in women undertaking a web-based multimodal lifestyle intervention: The Women's Wellness Program. Maturitas. 2015;81(1):69-75.

doi:10.1016/j.maturitas.2015.02.263

27. Bener A, Saleh NM, Bakir A, Bhugra D. Depression, Anxiety, and Stress Symptoms in Menopausal Arab Women: Shedding More Light on a Complex Relationship. Ann
Med Health Sci Res. 2016;6(4):224-231. doi:10.4103/amhsr.amhsr_341_15 
Table (1): Basic Characteristics of the Studied Menopausal Women from Outpatient Clinic in Tanta University Hospital ( $\mathrm{N}=200)$

\begin{tabular}{|c|c|c|}
\hline \multirow[t]{2}{*}{ Variables } & \multicolumn{2}{|c|}{$\begin{array}{l}\text { The studied menopausal women } \\
\qquad(\mathrm{n}=200)\end{array}$} \\
\hline & No. & $\%$ \\
\hline \multicolumn{3}{|l|}{ Age years: } \\
\hline - $\quad 45-<55$ & 34 & 17.0 \\
\hline - $\geq 55$ & 168 & 83.0 \\
\hline \multicolumn{3}{|l|}{ Residence: } \\
\hline - Urban & 50 & 25.0 \\
\hline - $\quad$ Rural & 150 & 75.0 \\
\hline \multicolumn{3}{|l|}{ Marital status: } \\
\hline - Married & 132 & 66.0 \\
\hline - Widow & 56 & 28.0 \\
\hline - $\quad$ Divorced & 12 & 6.0 \\
\hline \multicolumn{3}{|l|}{ Number of offspring: } \\
\hline - $<3$ & 70 & 35.0 \\
\hline - $3-4$ & 54 & 27.0 \\
\hline - $\geq 5$ & 76 & 38.0 \\
\hline \multicolumn{3}{|l|}{ Education level: } \\
\hline - $\quad$ Illiterate & 104 & 52.0 \\
\hline - $\quad$ Read and write & 32 & 16.0 \\
\hline - Secondary school & 40 & 20.0 \\
\hline - University & 24 & 12.0 \\
\hline \multicolumn{3}{|l|}{ Employment: } \\
\hline - Employed & 48 & 24.0 \\
\hline - Unemployed & 152 & 76.0 \\
\hline \multicolumn{3}{|l|}{ Family income: } \\
\hline - Enough & 164 & 82.0 \\
\hline - Not enough & 36 & 18.0 \\
\hline \multicolumn{3}{|l|}{ Accommodation: } \\
\hline - With their family & 192 & 96.0 \\
\hline - Not living with their family & 8 & 4.0 \\
\hline \multicolumn{3}{|l|}{ Type of family: } \\
\hline - Cohesive family & 192 & 96.0 \\
\hline - Disjoined family & 8 & 4.0 \\
\hline \multicolumn{3}{|l|}{ Smoking: } \\
\hline - Yes & 22 & 11.0 \\
\hline - $\mathrm{No}$ & 178 & 89.0 \\
\hline \multicolumn{3}{|l|}{ Perceived overweight /obesity: } \\
\hline - Yes & 154 & 77.0 \\
\hline - $\mathrm{No}$ & 46 & 23.0 \\
\hline \multicolumn{3}{|l|}{ Suffer from chronic disease: } \\
\hline - Yes & 146 & 73.0 \\
\hline - $\mathrm{No}$ & 54 & 27.0 \\
\hline
\end{tabular}


Table (2) Scores and Ranks of Health-Promoting Lifestyle Profile-II (HPLP-II) Domains among the Studied Menopausal Women from Outpatient Clinic in Tanta University Hospital (N=200)

\begin{tabular}{|c|c|c|c|c|}
\hline \multirow{2}{*}{$\begin{array}{l}\text { Health-Promoting Lifestyle } \\
\text { Profile-II (HPLPII) domains } \\
\text { (Each item was scored 1-4) }\end{array}$} & \multirow[t]{2}{*}{$\begin{array}{l}\text { No. of items } \\
\text { (Score range) }\end{array}$} & \multicolumn{3}{|c|}{$\begin{array}{l}\text { Scores and ranks of HPLPII domains among of the } \\
\text { studied menopausal women } \\
(n=200)\end{array}$} \\
\hline & & \multirow{2}{*}{$\begin{array}{c}\text { Range } \\
\text { Mean } \pm \text { SD }\end{array}$} & \multirow{2}{*}{$\begin{array}{c}\text { Range } \\
\text { Mean } \pm \text { SD } / \text { No. of } \\
\text { items }\end{array}$} & \multirow[t]{2}{*}{ Rank } \\
\hline & & & & \\
\hline - Health-responsibility & $\begin{array}{c}9 \\
(9-36)\end{array}$ & $\begin{array}{c}13-27 \\
19.44 \pm 4.59\end{array}$ & $\begin{array}{c}1-3 \\
2.16 \pm 0.51\end{array}$ & 5 \\
\hline - Physical Activity & $\begin{array}{c}8 \\
(8-32)\end{array}$ & $\begin{array}{c}8-21 \\
11.43 \pm 3.68\end{array}$ & $\begin{array}{c}1-3 \\
1.43 \pm 0.46\end{array}$ & 6 \\
\hline - $\quad$ Nutrition & $\begin{array}{c}9 \\
(9-36)\end{array}$ & $\begin{array}{c}16-27 \\
20.89 \pm 2.86\end{array}$ & $\begin{array}{c}2-3 \\
2.32 \pm 0.32\end{array}$ & 4 \\
\hline - $\quad$ Spiritual Growth & $\begin{array}{c}9 \\
(9-36)\end{array}$ & $\begin{array}{c}14-36 \\
25.52 \pm 5.34\end{array}$ & $\begin{array}{c}1-4 \\
2.84 \pm 0.59\end{array}$ & 1 \\
\hline - Interpersonal Relations & $\begin{array}{c}9 \\
(9-36)\end{array}$ & $\begin{array}{c}14-36 \\
24.32 \pm 5.40\end{array}$ & $\begin{array}{c}1-4 \\
2.70 \pm 0.60\end{array}$ & 2 \\
\hline - $\quad$ Stress Management & $\begin{array}{c}8 \\
(8-32)\end{array}$ & $\begin{array}{c}12-31 \\
18.78 \pm 4.53\end{array}$ & $\begin{array}{c}1-4 \\
2.35 \pm 0.57\end{array}$ & 3 \\
\hline Total HPLPII Scores & $\begin{array}{c}52 \\
(52-208)\end{array}$ & $\begin{array}{c}95-161 \\
120.38 \pm 16.63\end{array}$ & & \\
\hline
\end{tabular}

Table (3): Scores and Ranks of Menopause Rating Scale (MRS) Subscales among the Studied Menopausal Women from Outpatient Clinic in Tanta University Hospital ( $=200)$

\begin{tabular}{|c|c|c|c|c|}
\hline $\begin{array}{l}\text { Menopause Rating Scale (MRS) } \\
\text { symptoms subscales }\end{array}$ & $\begin{array}{l}\text { No. of } \\
\text { items } \\
\text { (Score) }\end{array}$ & \multicolumn{3}{|c|}{$\begin{array}{l}\text { Scores and ranks of MRS subscales among of the studied } \\
\text { menopausal women } \\
\qquad(\mathrm{n}=200)\end{array}$} \\
\hline (Each item was scored 0-4) & & \multirow{2}{*}{$\begin{array}{c}\text { Range } \\
\text { Mean } \pm \text { SD }\end{array}$} & \multirow{2}{*}{$\begin{array}{c}\text { Range } \\
\text { Mean } \pm \text { SD/No. of } \\
\text { items }\end{array}$} & \multirow[t]{2}{*}{ Rank } \\
\hline & & & & \\
\hline $\begin{array}{l}\text { - Somato-vegetative } \\
\text { symptoms }\end{array}$ & $\begin{array}{c}4 \\
(0-16)\end{array}$ & $\begin{array}{c}3-12 \\
7.83 \pm 2.19\end{array}$ & $\begin{array}{c}1-3 \\
1.96 \pm 0.55\end{array}$ & 1 \\
\hline - $\quad$ Psychological symptoms & $\begin{array}{c}4 \\
(0-16)\end{array}$ & $\begin{array}{c}1-10 \\
5.80 \pm 2.51\end{array}$ & $\begin{array}{c}0-3 \\
1.45 \pm 0.63\end{array}$ & 2 \\
\hline - Urogenital symptoms & $\begin{array}{c}3 \\
(0-12)\end{array}$ & $\begin{array}{c}0-7 \\
4.31 \pm 2.09\end{array}$ & $\begin{array}{c}0-2 \\
1.44 \pm 0.70\end{array}$ & 3 \\
\hline $\begin{array}{c}\text { Total Menopause Rating Scale } \\
\text { Scores }\end{array}$ & $\begin{array}{c}11 \\
(0-44)\end{array}$ & $\begin{array}{c}12-27 \\
17.94 \pm 3.90\end{array}$ & & \\
\hline
\end{tabular}


Table (4): Correlation between Scores of Menopause Rating Scale (MRS) Subscales aAnd Scores of HealthPromoting Lifestyle Profile-II (HPLP-II) Domains among The Studied Menopausal Women from Outpatient Clinic in Tanta University Hospital (N=200).

\begin{tabular}{|c|c|c|c|c|}
\hline \multirow[t]{2}{*}{$\begin{array}{l}\text { Health-Promoting Lifestyle } \\
\text { Profile-II (HPLP-II) } \\
\text { domains }\end{array}$} & \multicolumn{4}{|c|}{ 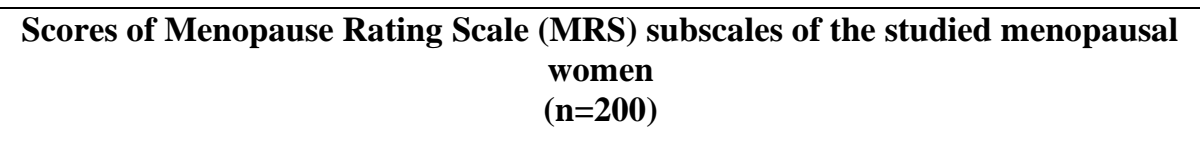 } \\
\hline & $\begin{array}{c}\text { Somato-vegetative } \\
\text { symptoms }\end{array}$ & $\begin{array}{l}\text { Psychological } \\
\text { symptoms }\end{array}$ & $\begin{array}{l}\text { Urogenital } \\
\text { symptoms }\end{array}$ & Total MRS scores \\
\hline & $\begin{array}{l}\mathbf{r} \\
\mathbf{p}\end{array}$ & $\begin{array}{l}\mathbf{r} \\
\mathbf{p}\end{array}$ & $\begin{array}{l}\mathbf{r} \\
\mathbf{p}\end{array}$ & $\begin{array}{l}\mathbf{r} \\
\mathbf{p}\end{array}$ \\
\hline - Health-responsibility & $\begin{array}{c}-0.107 \\
0.291\end{array}$ & $\begin{array}{c}-0.367 \\
0.0001 *\end{array}$ & $\begin{array}{l}-0.192 \\
0.056\end{array}$ & $\begin{array}{l}-0.279 \\
0.005^{*}\end{array}$ \\
\hline - Physical Activity & $\begin{array}{l}-0.160 \\
0.112\end{array}$ & $\begin{array}{l}-0.215 \\
0.032 *\end{array}$ & $\begin{array}{c}-0.541 \\
0.0001 *\end{array}$ & $\begin{array}{l}-0.518 \\
0.0001 *\end{array}$ \\
\hline - $\quad$ Nutrition & $\begin{array}{c}-0.701 \\
0.0001 *\end{array}$ & $\begin{array}{l}-0.177 \\
0.078\end{array}$ & $\begin{array}{c}-0.519 \\
0.0001 *\end{array}$ & $\begin{array}{c}-0.499 \\
0.0001 *\end{array}$ \\
\hline - $\quad$ Spiritual Growth & $\begin{array}{l}-0.084 \\
0.408\end{array}$ & $\begin{array}{c}-0.401 \\
0.0001 *\end{array}$ & $\begin{array}{c}-0.896 \\
0.0001 *\end{array}$ & $\begin{array}{c}-0.404 \\
0.0001 *\end{array}$ \\
\hline - Interpersonal Relations & $\begin{array}{l}-0.033 \\
0.745\end{array}$ & $\begin{array}{l}0.145 \\
0.151\end{array}$ & $\begin{array}{c}-0.920 \\
0.0001^{*}\end{array}$ & $\begin{array}{c}-0.447 \\
0.0001 *\end{array}$ \\
\hline - $\quad$ Stress Management & $\begin{array}{c}-0.732 \\
0.0001 *\end{array}$ & $\begin{array}{c}-0.690 \\
0.0001 *\end{array}$ & $\begin{array}{c}-0.893 \\
0.0001^{*}\end{array}$ & $\begin{array}{c}-0.572 \\
0.0001 *\end{array}$ \\
\hline Total HPLP-II scores & $\begin{array}{l}0.086 \\
0.393\end{array}$ & $\begin{array}{c}-0.543 \\
0.0001 *\end{array}$ & $\begin{array}{c}-0.915 \\
0.0001 *\end{array}$ & $\begin{array}{l}-0.865 \\
0.0001 *\end{array}$ \\
\hline
\end{tabular}

*Significant $(\mathrm{P}<0.05)$

$\mathrm{r}=$ Correlation Coefficient 
Table (5): Total Menopause Rating Scale (MRS) and Total Health-Promoting Lifestyle Profile-II (HPLPII) in Relation to Basic Characteristics of the Studied Menopausal Women from Outpatient Clinic in Tanta University Hospital ( $\mathbf{N}=\mathbf{2 0 0})$.

\begin{tabular}{|c|c|c|c|c|}
\hline \multirow[t]{2}{*}{ Basic characteristics } & \multicolumn{4}{|c|}{$\begin{array}{l}\text { Total scores of the studied menopausal women } \\
(n=200)\end{array}$} \\
\hline & Total MRS scores & $\begin{array}{l}\text { t-test of } F \\
\text { value }\end{array}$ & $\begin{array}{l}\text { Total HPLP-II } \\
\text { scores }\end{array}$ & $\begin{array}{l}\text { t-test of } F \\
\text { value }\end{array}$ \\
\hline & Mean \pm SD & $\mathbf{p}$ & Mean \pm SD & $\mathbf{p}$ \\
\hline \multicolumn{5}{|l|}{ Age years: } \\
\hline - $45-<55$ & $16.53 \pm 2.50$ & 1.649 & $121.82 \pm 14.33$ & 0.391 \\
\hline - $\geq 50$ & $18.23 \pm 4.08$ & 0.102 & $120.08 \pm 17.12$ & 0.697 \\
\hline \multicolumn{5}{|l|}{ Residence: } \\
\hline - Urban & $16.16 \pm 3.02$ & 2.715 & $116.56 \pm 17.94$ & 1.331 \\
\hline - Rural & $18.53 \pm 4.00$ & $0.008^{*}$ & $121.65 \pm 16.09$ & 0.186 \\
\hline \multicolumn{5}{|l|}{ Marital status: } \\
\hline - Married & $18.33 \pm 3.87$ & 5.634 & $123.57 \pm 18.03$ & 4.721 \\
\hline - Widow & $18.07 \pm 3.74$ & $0.005^{*}$ & $112.50 \pm 11.89$ & $0.011^{*}$ \\
\hline - $\quad$ Divorced & $13.00 \pm 0.00$ & & $122.00 \pm 0.00$ & \\
\hline \multicolumn{5}{|l|}{ Number of offspring: } \\
\hline$->3$ & $17.11 \pm 3.22$ & 9.449 & $130.94 \pm 17.44$ & 8.087 \\
\hline - $3-4$ & $20.15 \pm 4.91$ & $0.0001 *$ & $116.44 \pm 9.00$ & $0.0001 *$ \\
\hline - $\geq 5$ & $17.13 \pm 3.07$ & & $113.45 \pm 15.40$ & \\
\hline \multicolumn{5}{|l|}{ Education level: } \\
\hline - Illiterate & $18.86 \pm 4.24$ & 2.941 & $116.75 \pm 13.99$ & 17.153 \\
\hline - $\quad$ Read \& write & $18.12 \pm 2.50$ & $0.037 *$ & $107.00 \pm 14.42$ & $0.0001^{*}$ \\
\hline - Secondary school & $16.25 \pm 3.43$ & & $137.15 \pm 15.43$ & \\
\hline - Faculty & $16.50 \pm 3.65$ & & $126.00 \pm 4.18$ & \\
\hline \multicolumn{5}{|l|}{ Job: } \\
\hline - $\quad$ Employed & $16.75 \pm 3.34$ & 1.730 & $126.25 \pm 3.10$ & 2.0104 \\
\hline - Unemployed & $18.31 \pm 4.01$ & 0.087 & $118.53 \pm 18.64$ & $0.047 *$ \\
\hline \multicolumn{5}{|l|}{ Income: } \\
\hline - Enough & $18.00 \pm 4.13$ & 0.326 & $119.88 \pm 17.85$ & 0.642 \\
\hline - Not enough & $17.67 \pm 2.70$ & 0.745 & $122.67 \pm 9.25$ & 0.522 \\
\hline \multicolumn{5}{|l|}{ Living accommodation: } \\
\hline - With their family & $18.10 \pm 3.90$ & 2.094 & $121.44 \pm 16.12$ & 3.264 \\
\hline $\begin{array}{l}\text { - Not living with their } \\
\text { family }\end{array}$ & $14.00 \pm 0.00$ & $0.039 *$ & $95.00 \pm 0.00$ & $0.002 *$ \\
\hline \multicolumn{5}{|l|}{ Type of family: } \\
\hline - Cohesive family & $18.10 \pm 3.90$ & 2.094 & $121.44 \pm 16.12$ & 3.264 \\
\hline - Disjoined family & $14.00 \pm 0.00$ & $0.039^{*}$ & $95.00 \pm 0.00$ & $0.002 *$ \\
\hline \multicolumn{5}{|l|}{ Smoking: } \\
\hline - Yes & $20.91 \pm 1.04$ & 2.761 & $123.64 \pm 1.57$ & 0.687 \\
\hline - $\mathrm{No}$ & $17.57 \pm 3.97$ & $0.007 *$ & $119.9817 .59 \pm$ & 0.494 \\
\hline \multicolumn{5}{|l|}{$\begin{array}{l}\text { Suffer from overweight } \\
\text { /obesity: }\end{array}$} \\
\hline - Yes & $18.13 \pm 3.84$ & 0.889 & $120.31 \pm 18.02$ & 0.075 \\
\hline - $\mathrm{No}$ & $17.30 \pm 4.14$ & 0.376 & $120.61 \pm 11.04$ & 0.941 \\
\hline \multicolumn{5}{|l|}{ Suffer from chronic disease: } \\
\hline - $Y e s$ & $18.08 \pm 3.93$ & 0.597 & $119.56 \pm 18.80$ & 0.808 \\
\hline - $\mathrm{No}$ & $17.55 \pm 3.88$ & 0.552 & $122.59 \pm 8.19$ & 0.421 \\
\hline
\end{tabular}




\section{أعراض انقطاع الطمث وسلوكيات نمط الحياة المعززة للصحمة العربي بين النساء في طنطا، مصر: دراسة مقطعية تحليلة}

إيهاب عبد الحليم أبو علي - آيات عبد الرؤف عكه أنطا

الخلفية: على الرغم من أن انقطاع الطمث يعتبر مرحلة طبيعية في حياة المر أة ، إلا أنه غالبا ما يعاني عدد كبير من النساء من مشاكل

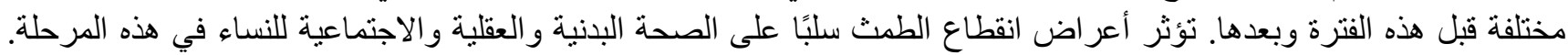

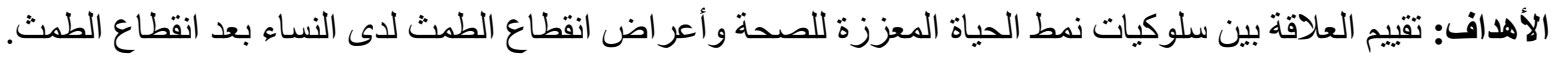

المشاركون والطرق: تم اختيار مائتي امر أة في مرحلة انقطاع الطمث بشكل عشو ائي من جميع المترددات علي العيادات الخارجية

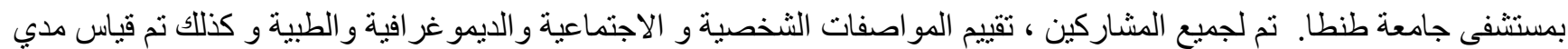
نمط الحياة المعزز للصحة (HPLP-II) II ومقياس درجة أعر اض انقطاع الطمث (MRS) من خلال استبيان ذاني أو المقابلة شخصية.

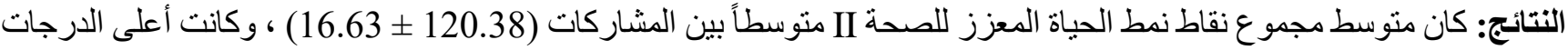

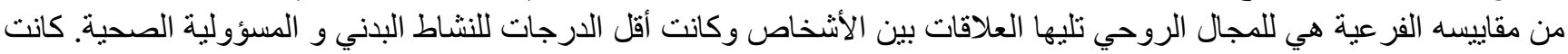

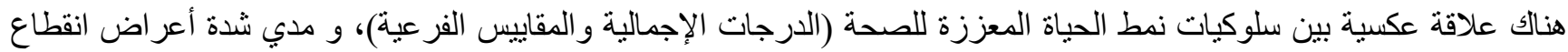

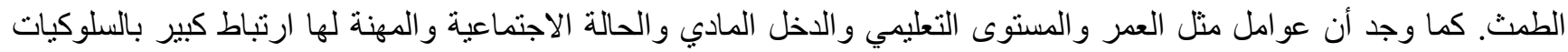

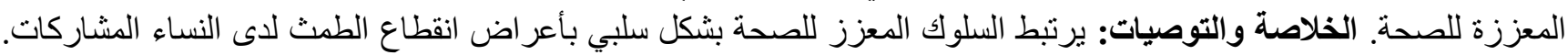
لذلك ، يمكن استخدام بر امج التنقيف الصحي حول أنماط الحياة التي تعزز الصحة لتقليل أعر اض انقطاع الطمث لإى النساء وتحسين نوعية حياتهن. 